\title{
Services Effect on Motivation Spirituality Healing Patiens in the Hospital Literature Review
}

\author{
Antina Atik ${ }^{1}$, Yully Peristiowati ${ }^{2}$, Agusta D. Ellina ${ }^{3}$ \\ 1,2,3 Master Nursing Program, Nursing School, Institute Health Sciences of \\ Strada Indonesia \\ Email: antinaatikk7@gmail.com
}

\begin{abstract}
Healing motivation is a force that drives patients to take action to return to health. One way to increase the motivation of the patient's healing is to provide spiritual services, namely spiritual therapy. Many studies have shown that spiritual activity can increase a person's motivation and adaptation when experiencing pain as found in some of these studies on Spirituality from the results of existing research, by Karina Dinda Kinasih Aries Wahyuningsih, about the role of spiritual assistance in elderly patients in the Adult Inpatient Installation. The majority of Kediri Baptist Hospitals are good, namely 69 respondents (90\%). The motivation for healing in elderly patients at the Adult Inpatient Installation of Baptist Hospital Kediri is a strong majority, namely 72 respondents (90\%). Spiritual experiences experienced by patients studied by Fitriani Mailani with the title Spiritual Experiences in Chronic Kidney Disease undergoing Hemodialysis, where researchers explore spirituality in chronic kidney disease patients undergoing hemodialysis. The data was obtained through interviews with respondents, so that several themes were obtained, namely getting closer to God, support from the closest people, having high hopes for recovery, and accepting sincerely the illness they suffered, and having high hopes for recovery, such as trying non-medical treatment, believing miraculously and always pray for healing. The difference between spirituality and religiosity nursing problems in type-2 diabetes mellitus patients is directed at how nurses understand the concepts of spirituality and religiosity. Research by llhamsyah who looked at the relationship between the implementation of spiritual nursing and the spiritual satisfaction of hospital patients showed a significant relationship between the implementation of spiritual nursing and the spiritual satisfaction of patients with a significance level of $P=0.033$. And several other studies say that the healing rate for patients with spiritual/spiritual assistance is quite high, so it is very important for hospitals to provide and determine the existence of spiritual assistance teams from various interfaith religions to provide motivation and spiritual needs of patients in accordance with the rights and obligations obtained in hospital services.
\end{abstract}

Keywords: Influence, Spiritual Service, Healing Motivation.

\section{A. INTRODUCTION}

Spiritual condition is one aspect of attention to improve the degree of health, as explained in the definition of health in general, namely a state of balance in the physical, social, spiritual and mental conditions so that a person is aware of his ability to cope with pressure and can work productively so that he can contribute to environment (WHO), further according to (Dadang Hawari, 2015) that treatment accompanied by religious therapy (Psychoreligious) for health problems has more optimal benefits when compared to treatment that is not accompanied by religious therapy (Psychoreligious). 
Values that shape and influence our lives are eternal values and health. A person's health depends on a balance of physical, psychological, social, cultural, developmental and spiritual variables. Nurses have a traditional approach to health promotion through a holistic perspective. The fundamental assumption about holism is the belief that individuals cannot divide them into component parts; the individual as a whole is greater than the sum of the parts (Mansen, 1993). Spiritual well-being is an integrated aspect of the whole human being that is characterized by meaning and hope (Clark et al., 1991).

Patients undergoing inpatient treatment at the hospital are undergoing a stage of the physical, psychosocial and spiritual healing process for the patient. Therefore, in terms of psychology, spiritual aspects, and spiritual aspects of patients at this stage need to be filled. It is this spiritual emptiness, spirituality, and religious feeling that gives rise to psycho-social in the field of mental health, experts argue that in order to fully understand humans, both in good health and even more so in illness, the approach no longer views humans as bio-psychosocial beings, but rather humans as bio-psycho-social-spiritual beings (Sudewo, 1996: 53).

Based on the Regulation of the Minister of Health number: 4 of 2018 Article 17 which regulates the obligation of every hospital to give patients the right to worship according to their religion and beliefs, as long as this does not interfere with other patients, but the hospital also respects the patient's decision to refuse spiritual guidance services that are not in accordance with their religion and beliefs.

Pain is an unpleasant condition that afflicts a person, causing disturbances in daily activities, both physical, social and spiritual activities (Parkins in Asmadi, 2008). According to the IHME (Institute for Health Matrics and Evaluation) in 2010 the prevalence of morbidity in Indonesia was $58 \%$ caused by non-communicable diseases, 33\% by infectious diseases and 9\% by injuries (Moeloek, 2015).

The concept of health formulated by WHO (World Health Organization). According to WHO (1950), "Health is a state of complete physical, mental and social well being not merely the absence of disease or infirmity". This understanding of health shows that illness contains a biopsychosocial dimension, namely disease, illness, and sickness (Calhoun in Notosoedirdjo \& Latipun, 2001).

Disease is a biological dimension, where symptoms are known through medical diagnosis. Illness is a psychological dimension, where a person's subjective experience of illness (discomfort) is on this dimension. Sickness is a sociological dimension, describing how social acceptance of someone as a sick person. Thus, two terms emerged to describe pain, namely disturbance and deviation. Disturbance is a medical and psychological concept in which clinically there is a disease or abnormality or disturbance of certain functions.

When a person is diagnosed with all diseases, all aspects of his life will be affected including the spiritual aspect and generally the sick individual has feelings of anxiety and fear over his existence and performance. Anxiety that often arises is caused by psychological dynamics, how long does it take to treat the disease, the amount of medical expenses that must be incurred, and the new situation that he 
has to depend on others both economically because he is no longer working and physically because of his weaknesses and limitations. In carrying out daily activities (Rahmadiana, 2009), in addition to the form of fear that is often felt by someone when sick includes fear of the disease not being cured, fear of death, fear of experiencing disability and fear of not getting recognition from the environment so that they feel isolated (Sunaryo, 2004). ). Spirituality is a source of motivation and individual emotions related to one's relationship with God, while religiosity is a special dedication to research to analyze what spiritual/religious aspects arise, analyze the characteristics of spiritual/religious aspects and analyze forms of implementation of spiritual/religious-based treatments that can Motivate patients to recover from their illness.

The impact of mental and emotional pain depends on a person's behavior and reactions as well as the origin of the disease, for example: severe illness, especially one that can threaten his life, can cause wider emotional and behavioral changes, such as: anxiety, shock, rejection, anger and withdrawal. It is a common response to stress caused by illness (Potter \& Perry, 2005). Physical and spiritual conditions affect each other, an unstable spiritual condition can affect physical conditions, so that it often brings diseases related to the body, and vice versa (Hawari, 2008). An unstable mental state besides being able to worsen the physical condition will also cause negative feelings/thoughts in the patient, negative feelings/thoughts made by someone in the treatment process will cause a decrease in the ability to deal with anxiety, low expectations and lack of self-confidence, The attitude of pessimism that often arises is a feeling of inadequacy, hopelessness and other negative thoughts which can ultimately lead to low motivation to recover from a disease that is being suffered by a person (Ahmad, 2010). A spiritual approach can be done in the form of patience and fortitude in the face of an illness will be able to help a person in reducing a suffering, if the suffering is reduced which can directly rebuild a confidence, find life hope and peace in the midst of the existential illness (Hawari, 2013).

Medical experts realize that humans are not merely physical material, but behind it, he has another dimension, which is seen as human nature such as the spiritual dimension (spiritual). Therefore, it is impossible for humans to be able to live life without equipping the two elements that exist in themselves. The human spirit that sustains his physical life should not be neglected in life. If the physical dimension can live and feel happy with material food, then the human spirit will be able to live and feel at ease with spiritual food. Faith and belief are human spiritual food (Ali, 2002). Spiritual therapy through spiritual guidance is one of the efforts to increase the motivation to heal patients through extrinsic encouragement in the form of support from the social environment, such as: family, doctors, nurses andofficers hospital clergyby reminding patients of the strengths that (The Greatness of God Almighty) by instilling religious spiritual values. According to (Chabibah, 2011) spiritual guidance is the actualization of theology which is manifested in an activity of believing human beings as social beings which is carried out regularly to foster 
and direct a person so that his belief is solid to fear God Almighty, obedient to worship and strengthen religious awareness so that it can bring a person or patient to a calmer mental state The phenomenon of depression is found in many today, researchers found the phenomenon of depression in the research city itself, which is located in Bintalu, Sarawak, Malaysia. According to the researcher's interview with employees of the Hal Ihwal Islam Hospital Bintulu unit, there have been 10 cases of depression that have occurred among individuals who are Muslim recently (interview with Ustadz Khairol Nizam Latif, employee of the Hal Ihwal Islam Hospital Bintulu unit, 31-May-2019).

Motivation of healing in chronic disease patients that $38.9 \%$ of the 36 respondents had low healing motivation (Saradi, Kirana, \& Saragih, 2011). The framework of thought here is that every human soul needs religion because humans consist of two different substances, namely material needs and immaterial souls, without religion the human soul cannot feel peace and happiness in life.

Based on the results of this study, the researchers were interested in conducting a literature review study with the title "The Effect of Spiritual Services on Motivation for Healing Patients in Inpatient Rooms at Hospitals" . This research is important to do because it is to determine the extent of the influence of spiritual services on the motivation of healing patients. The purpose of this study was to determine the effect of spiritual services on the motivation of healing in inpatients in the inpatient room at the hospital.

\section{B. METHOD}

This research is a research using literature study method or literature review. The literature review is a comprehensive overview of the research that has been done on a specific topic (Denney \& Tewksbury, 2013). Literature review is a thematic synthesis compiled from sources that can be used by readers to get a summary of the theory and the latest empirical findings according to the topic (Cisco, 2014). The type of literature review used in this study is a scoping review. Scoping review is a relatively new review method, used to clarify the working definition and conceptual boundaries of a topic or field, especially to review literature that has not been reviewed comprehensively, is complex or heterogeneous which does not allow for a systematic review. Scoping reviews can be used to summarize and disseminate research findings, to identify research gaps, and make recommendations for further research (Peters et al., 2015).

The literature search was carried out by identifying all types of national and international articles regarding the influence of spiritual services on patient recovery. The data base electronic used is PubMed, Elsevier, Wiley, and Google Scholar. The keywords used in the literature search are a combination of keywords such as the following: Religion, Spirituality and Spiritual Service. The search results are limited to 2015 to 2019 and manually select articles that are relevant or in accordance with the research question (Figure 1). The inclusion criteria of the article are: (1) The participant is Spiritual, Religious (2) The intervention used is spiritual service, (3) 
The results of the study show that there is an influence on the motivation to heal, while the exclusion criteria are articles that are not in English and are not relevant to the research question.

The analytical method used is journal content analysis. Statements from the research results that were reviewed were then grouped by theme, then coding was done using the category of spiritual/religious aspects.

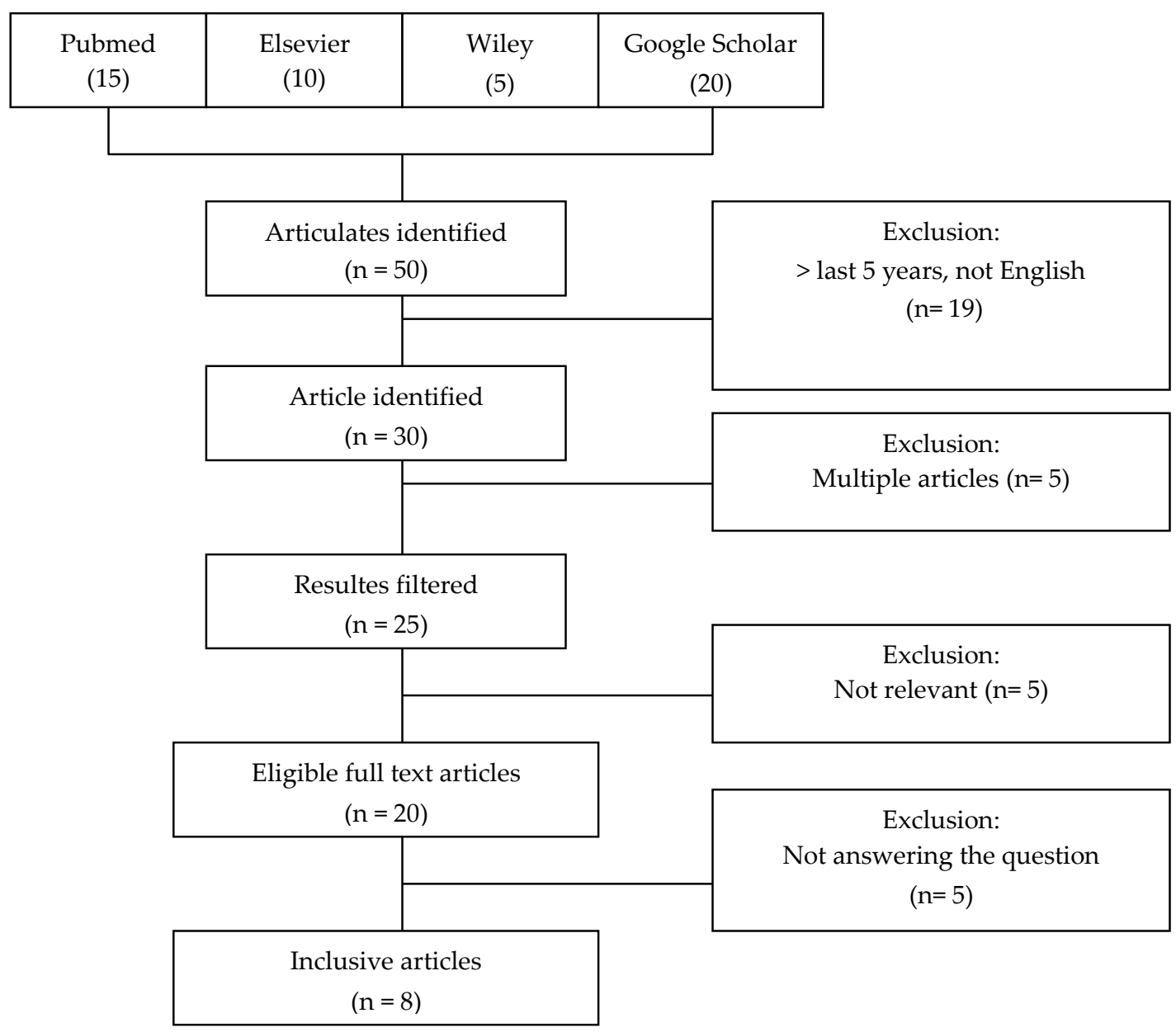

Figure 1. Search Algorithm 
Table 1 Assessing Article Quality Based on Literature Study Findings

\begin{tabular}{|c|c|c|c|c|c|c|c|}
\hline No & Author & $\begin{array}{c}\text { Journal Name } \\
\text { Volume, No, } \\
\text { Year }\end{array}$ & Title & $\begin{array}{c}\text { Method } \\
\text { (Design, sample, Variable, } \\
\text { Instrument, Analysis) }\end{array}$ & Research Results & $\begin{array}{l}\text { Differences } \\
\text { with research } \\
\text { current }\end{array}$ & Database \\
\hline 1 & $\begin{array}{l}\text { Karina Dinda } \\
\text { Kinasih Aries } \\
\text { Wahyuning }\end{array}$ & $\begin{array}{l}\text { STIKES } \\
\text { Volume 5, } \\
\text { No.1, July } \\
\text { 2012Journal }\end{array}$ & $\begin{array}{l}\text { Role of Mentoring } \\
\text { Spiritual } \\
\text { Motivation } \\
\text { Recovery in } \\
\text { Patients Elderly }\end{array}$ & $\begin{array}{l}\text { The design is using cross sectional, } \\
\text { and the measurement time is } \\
\text { observation and only one time at } \\
\text { that time, and the sampling } \\
\text { technique used is Consecutive } \\
\text { Sampling. With the sample criteria } \\
\text { of elderly patients in the Adult } \\
\text { Inpatient Installation, RS. Baptists } \\
\text { in Kediri from September } 2010 \text { to } \\
\text { January } 2011 \text { were } 506 \text { people, so } \\
\text { the average per month is } 101 \\
\text { patients. Hospital Pastoral Officer. } \\
\text { Baptist Kediri totaled } 13 \text { people. } \\
\text { And analyzed the Relationship } \\
\text { between the Role of Spiritual } \\
\text { Assistance with Motivation Healing } \\
\text { in Elderly Patients in the Adult } \\
\text { Inpatient Installation of Baptist } \\
\text { Hospital Kediri. }\end{array}$ & $\begin{array}{l}\text { Statistical test was Spearman } \\
\text { Rhocarried out with SPSS } \\
\text { version 15, based on the } \\
\text { significance level set }=0.05 \text {, } \\
\text { it was obtained = } 0.000 \text {, } \\
\text { where < which means H0 is } \\
\text { rejected and H1 is accepted. } \\
\text { So there is a significant } \\
\text { relationship between the } \\
\text { role of spiritual mentoring } \\
\text { and motivation for healing } \\
\text { in elderly patients at the } \\
\text { Adult Inpatient Installation } \\
\text { of Baptist Hospital Kediri. } \\
\text { The number of correlation } \\
\text { coefficient (Correlation } \\
\text { Coefficient) is 0.574 which } \\
\text { means the correlation is } \\
\text { strong (Sujianto, 2009). The } \\
\text { results of analysis of the } \\
\text { statistical tests showed that } \\
\text { the role of Spiritual } \\
\text { assistance for elderly } \\
\text { patients has a strong } \\
\text { relationship in growing } \\
\text { strong motivation to recover } \\
\text { in elderly patients. }\end{array}$ & $\begin{array}{l}\text { Influence Services } \\
\text { Chaplaincy } \\
\text { Motivation } \\
\text { Healing. }\end{array}$ & \\
\hline
\end{tabular}




\begin{tabular}{|c|c|c|c|c|c|c|}
\hline 2 & $\begin{array}{l}\text { Fitri } \\
\text { Mailani }\end{array}$ & $\begin{array}{l}\text { Volume } \\
\text { Number } \\
\text { April } 2015\end{array}$ & $\begin{array}{l}\text { Experiences of } \\
\text { Spirituality in } \\
\text { Chronic Kidney } \\
\text { Disease Patients } \\
\text { undergoing } \\
\text { Hemodialysis }\end{array}$ & $\begin{array}{l}\text { This study is a descriptive } \\
\text { phenomenology, research design } \\
\text { that involves direct exploration. } \\
\text { With } 10 \text { participants from dr } \\
\text { Pirnagadi General Hospital and } \\
\text { Haji Adam Malik Hospital Medan, } \\
\text { which were taken by purposive } \\
\text { sampling method. } \\
\text { Consists of: } \\
\text { Men as many as } 6 \text { people. Duration } \\
\text { of hemodialysis ranges from } 4 \\
\text { months to } 10 \text { years and the majority } \\
\text { is more than } 1 \text { year. The majority of } \\
\text { participants are Muslim and are } \\
\text { Batak. The range of levels education } \\
\text { varies from junior high school } \\
\text { graduation to tertiary education } \\
\text { and all participants are married. } \\
\text { And by exploring Spirituality } \\
\text { inpatients chronic kidney disease } \\
\text { undergoing hemodialysis. } \\
\text { The data were obtained through } \\
\text { interviews with respondents, so } \\
\text { that several themes were obtained, } \\
\text { namely getting closer to God, } \\
\text { support from the closest people, } \\
\text { having high hopes for recovery, and } \\
\text { accepting sincerely the illness } \\
\text { suffered idealistic value. } \\
\text { Spirituality sees the biggest factor } \\
\text { influencing the suffering of type- } 2 \\
\text { diabetes mellitus patients is the } \\
\text { patient's internal condition (40), }\end{array}$ & $\begin{array}{l}\text { The results of data } \\
\text { Qualitative analysis with in- } \\
\text { depth interviews obtained } \\
\text { four themes of spirituality in } \\
\text { chronic kidney disease } \\
\text { patients undergoing } \\
\text { hemodialysis, namely: } \\
\text { Getting closer to God. } \\
\text { Support from those closest } \\
\text { to you. Have high hopes for } \\
\text { recovery. } \\
\text { Accept with sincerity the } \\
\text { illness suffered. Getting } \\
\text { closer to God, such as } \\
\text { diligently worshiping, } \\
\text { Deepening knowledge } \\
\text { religious, and improving the } \\
\text { quality of worship in daily } \\
\text { life. }\end{array}$ & $\begin{array}{l}\text { Influence } \\
\text { Services. } \\
\text { Spirituality } \\
\text { Motivation } \\
\text { Healing }\end{array}$ \\
\hline
\end{tabular}




\begin{tabular}{|c|c|c|c|c|c|c|}
\hline & & & & $\begin{array}{l}\text { compared to clinical indicators only } \\
(5.8 \%) \text {. } \\
\text { This study proves that a person's } \\
\text { spirituality will determine the } \\
\text { success of the management of } \\
\text { chronic diseases (Karlsen \& Bru, } \\
2012 \text { ). }\end{array}$ & & \\
\hline 4 & $\begin{array}{l}\text { Anisatun } \\
\text { Nurfaridah }\end{array}$ & $\begin{array}{l}\text { Research in } \\
2017\end{array}$ & $\begin{array}{l}\text { The Effect of } \\
\text { Spiritual Guidance } \\
\text { Motivation Healing } \\
\text { on Patient at Dr. } \\
\text { Sardjito Hospital } \\
\text { Yogyakarta }\end{array}$ & $\begin{array}{l}\text { Random Sampling Technique is a } \\
\text { sampling technique used if the } \\
\text { population has homogeneous } \\
\text { members. } \\
\text { Data Analysis, with } 75 \text { subjects }\end{array}$ & $\begin{array}{l}\text { There is a Positive Effect of } \\
\text { Spiritual Guidance between } \\
\text { Healing Motivation. Results } \\
\text { showed the implementation } \\
\text { of nursing spiritual } \\
\text { relationship with the } \\
\text { spiritual satisfaction of } \\
\text { patients at Ibnu Sina } \\
\text { Hospital Makassar with P > } \\
0.05\end{array}$ & $\begin{array}{l}\text { Effect of Services } \\
\text { Chaplaincy } \\
\text { Motivation } \\
\text { Healing }\end{array}$ \\
\hline 5 & Ilhamsyah. & $\begin{array}{l}\text { Research in } \\
2018\end{array}$ & $\begin{array}{l}\text { Relationship } \\
\text { between } \\
\text { Implementation } \\
\text { and Nursing } \\
\text { Spiritual Patient } \\
\text { Spiritual } \\
\text { Satisfaction at the } \\
\text { IBNU Hospital } \\
\text { SINA MAKASSAR }\end{array}$ & $\begin{array}{l}\text { This research is an observational } \\
\text { study with a cross sectional study } \\
\text { design to see the relationship } \\
\text { between the implementation of } \\
\text { spiritual nursing and the spiritual } \\
\text { satisfaction of patients at the Ibnu } \\
\text { Sina Hospital Makassar. } \\
\text { Samples are taken as } 98 \text { people who } \\
\text { meet the inclusion and exclusion } \\
\text { criteria, and purposively. Data was } \\
\text { collected through observation, } \\
\text { questionnaires, and documentation. } \\
\text { The data were analyzed using the } \\
\text { relationship test Chi Square. }\end{array}$ & & $\begin{array}{l}\text { Effect of } \\
\text { Chaplaincy } \\
\text { Motivation } \\
\text { Healing Services. }\end{array}$ \\
\hline
\end{tabular}




\begin{tabular}{|c|c|c|c|c|c|c|}
\hline 6. & $\begin{array}{l}\text { Maryana } \\
\text { Erwan }\end{array}$ & $\begin{array}{lr}\text { CITRA } & \\
\text { DELIMA: } \\
\text { Scientific } \\
\text { Journal of } \\
\text { STIKES } \\
\text { Delima } \\
\text { Bangka } \\
\text { Belitung } \\
\text { ISSN: } \quad \text { 2087- } \\
2240 ; \text { e } \\
2655-0792 & \text { ISS: } \\
\end{array}$ & $\begin{array}{l}\text { Perceptions Nurses' } \\
\text { of Spiritual Care in } \\
\text { the Intensive Care } \\
\text { Room of the Unit }\end{array}$ & $\begin{array}{l}\text { Qualitative Engineering with a } \\
\text { phenomenological approach } \\
\text { descriptive. This research was } \\
\text { conducted in the Intensive Care } \\
\text { Unit (ICU) of Medika Stannia } \\
\text { Sungailiat Hospital, Bangka } \\
\text { Regency on June } 7 \text { - July } 20 \text { 2018, } \\
\text { with } 10 \text { informants in this study. } \\
\text { Consisting of } 8 \text { main informants, } \\
\text { namely nurses in the ICU room at } \\
\text { Medika Stannia Hospital, as well as } \\
2 \text { informants supporting, namely } \\
\text { the head of nursing and the head of } \\
\text { quality and nursing ethics. Data } \\
\text { collection tools are interview } \\
\text { guides, observation guidelines, } \\
\text { recording devices, writing } \\
\text { instruments. Data collection } \\
\text { methods are interviews and } \\
\text { observation. }\end{array}$ & $\begin{array}{l}\text { The results of the study } \\
\text { found } 5 \text { themes of nurses' } \\
\text { perceptions about spiritual } \\
\text { care in the ICU room at } \\
\text { Medika Stannia Sungailiat } \\
\text { Hospital, namely: Nurses' } \\
\text { understanding of spiritual } \\
\text { care. In this theme, nurses } \\
\text { understand spiritual care as } \\
\text { care related to the provision } \\
\text { of spiritual guidance, care } \\
\text { related to religion, and care } \\
\text { related to belief. How to } \\
\text { identify the patient's } \\
\text { spiritual care needs. The } \\
\text { sub-themes include asking } \\
\text { about religion/belief and } \\
\text { asking about the patient's } \\
\text { worship patterns. } \\
\text { Implementation of spiritual } \\
\text { care by nurses. Sub themes } \\
\text { include: implementation of } \\
\text { spiritual care by nurses are } \\
\text { undocumented, nurses } \\
\text { focused on physical care, } \\
\text { spiritual care is rarely done. }\end{array}$ & $\begin{array}{l}\text { Influence Services } \\
\text { Chaplaincy } \\
\text { Motivation } \\
\text { Healing }\end{array}$ \\
\hline 7 & $\begin{array}{l}\text { Meza } \\
\text { Belindiani } \\
\text { Azzahra, Aan } \\
\text { Nur'aeni, } \\
\text { Cecep Eli } \\
\text { Kosasih }\end{array}$ & $\begin{array}{l}\text { Journal of } \\
\text { Nursing Care } \\
\& \\
\text { Biomolecular - } \\
\text { Volume } 3 \text { No } 2 \\
\text { Year } 2018 \text { - } 94\end{array}$ & $\begin{array}{l}\text { Perceptions Student } \\
\text { Nursing } \quad \text { About } \\
\text { Care Spiritual } \\
\text { (Spirtual Care) }\end{array}$ & $\begin{array}{l}\text { Quantitative Descriptive Methods } \\
\text { involving third and fourth year } \\
\text { students totaling } 171 \text { respondents } \\
\text { were selected using the proportionate } \\
\text { stratified random sampling technique, } \\
\text { and using the Spiritual Care Giving } \\
\text { Scale (SCGS) Questionnaire. } \\
\text { The variables studied were } \\
\text { students' perceptions Nursing of }\end{array}$ & $\begin{array}{l}\text { All respondents have a } \\
\text { favorable perception of } \\
\text { spiritual care (Spiritual Care). }\end{array}$ & \\
\hline
\end{tabular}




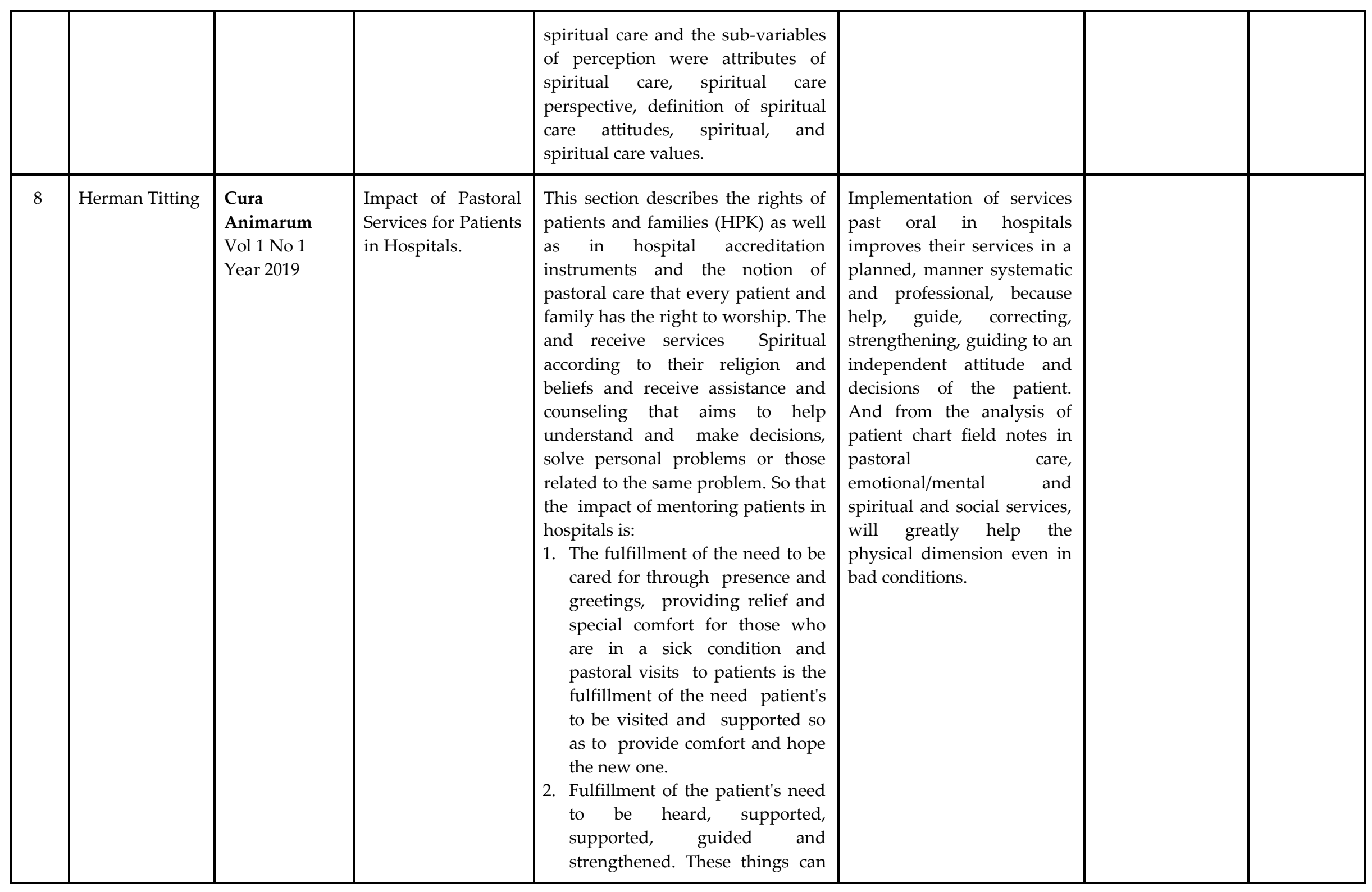




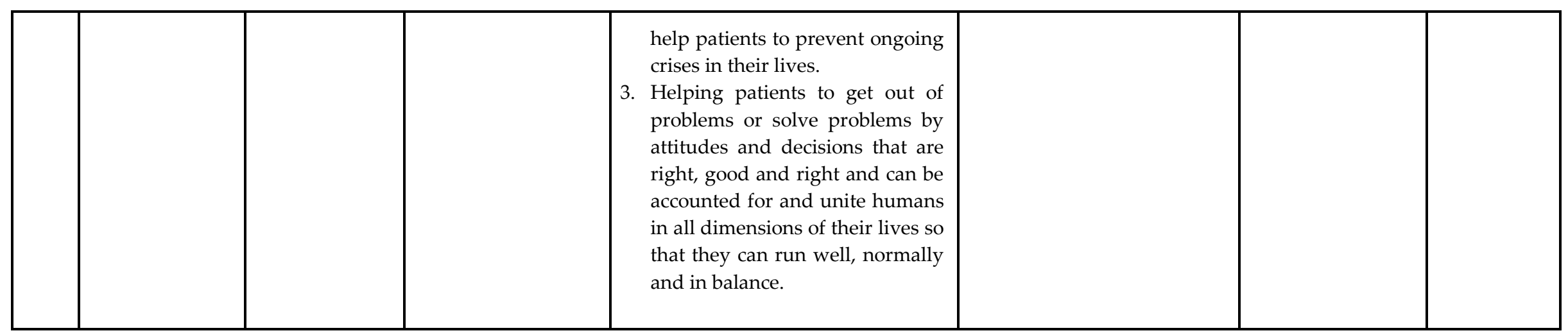




\section{RESULTS AND DISCUSSION}

From the results of the research studies presented based on the analyzed journal articles, the importance of spiritual/spiritual care that can motivate a person to influence the quality of life or recovery of patients in the hospital obtained the following results:

The Role of Spiritual Assistance from the results of research by Karina Dinda Kinasih Aries Wahyuningsih, regarding the role of spiritual assistance in elderly patients in the Adult Inpatient Installation of Kediri Baptist Hospital, the majority were good, namely 69 respondents (90\%). The motivation for healing in elderly patients at the Adult Inpatient Installation of Baptist Hospital Kediri is a strong majority, namely 72 respondents (90\%). Strong motivation of elderly patients to recover will support the nursing care provided, so that efforts to heal or improve patient health will be more easily achieved so that nurses are expected to provide holistic nursing care which includes biological, psychological, social and spiritual rituals in meeting the spiritual needs of patients with action. independently through establishing therapeutic communication to give patients peace of mind, giving privacy to pray, listening to patients when expressing their feelings and expressing acceptance of limitations or failures and also through collaborative actions with pastoral officers so as to increase motivation for healing elderly patients, and nurses who produced capable and competent in spiritual assistance to patients.

Spiritual experiences experienced by patients studied by Fitriani Mailani with the title Spiritual Experiences in Chronic Kidney Disease undergoing Hemodialysis, where researchers explore spirituality in chronic kidney disease patients undergoing hemodialysis. The data was obtained through interviews with respondents, so that several themes were obtained, namely getting closer to God, support from the closest people, having high hopes for recovery, and accepting sincerely the illness they suffered, and having high hopes for recovery, such as trying non-medical treatment, believing miraculously and always pray for healing. This shows that patients undergoing hemodialysis use a spirituality approach as a coping method to deal with their terminal illness.

For this reason, it is very important for nurses and families to approach spiritually to patients and provide support to improve the quality of life of patients, and nurses who work in hemodialysis rooms should create programs that support spirituality activities in groups according to the beliefs of each patient (support group). Nurses are expected to be able to provide nursing care with a spiritual approach (spiritual care) and holistically.

Spiritual care (spiritual care) is obtained in the study Iwan Ardian, Maryana Erwan And Meza Belindiani Azzahra, Aan Nur "Aeni, Cecelia Eli Kosasih. Spirituality Care which emphasizes that spiritual perspectives, spiritual care values, attributes of spiritual care, definitions of spiritual care, and spiritual care attitudes that can be used as information that can be used as evaluation material for nursing education institutions in forming competent nurses to meet all patient needs including the needs spiritual care, and make spiritual care as one of the important 
concepts in nursing, especially regarding aspects that are still lacking in respondents, namely the definition of spiritual care and spiritual care attitudes.

Spirituality is an inseparable part of the quality of individual life. Many researchers also argue that spiritual problems are a very important problem for patients suffering from chronic life-threatening diseases, for that it is necessary to approach a biopsychosocial-spiritual model in treating patients. Spirituality is an important dimension that must be considered in assessing the quality of life because spirituality disorders will cause severe psychological disorders including suicidal ideation (Bele et al., 2012). Spirituality is a broad concept with various dimensions and perspectives characterized by a feeling of attachment (connection) to something greater than ourselves, which is accompanied by an attempt to find meaning in life or can be explained as a universal and touching experience.

Diabetes can exert a negative impact on quality of life because diabetes is a lifelong chronic disease, diabetic patients have to deal with their disease all day long. The difference between spirituality and religiosity nursing problems in type- 2 diabetes mellitus patients is directed at how nurses understand the concepts of spirituality and religiosity. And the research that has been done, found 5 themes of nurses' perceptions about spiritual care in the ICU room at Medika Stannia Sungailiat Hospital, namely: Nurses' understanding of spiritual care. In this theme, nurses understand spiritual care as care related to the provision of spiritual guidance, care related to religion, and care related to belief. How to identify the patient's spiritual care needs. The sub-themes include asking about religion/belief and asking about the patient's worship patterns. The implementation of spiritual care by nurses. Sub-themes include: The implementation of spiritual care by nurses is not documented, nurses focus on physical care, and spiritual care is rarely done.

The influence of spiritual guidance on the implementation of spiritual nursing with spiritual satisfaction of patients in the hospital is a place for pastoral care to meet the needs of aspects of the patient's life, this requires cooperative cooperation of all parties in the hospital for the safety of patient healing. Pastoral services exist to strengthen, support, guide patients in facing and solving every struggle they face. From the analysis of field notes, namely charts of patients in pastoral care, emotional/mental and spiritual and social services, will greatly help the physical dimension even in bad conditions. The impact of pastoral care that can be felt by patients in hospitals are: first, the impact of visiting services on patients, namely: meeting the need to be cared for through presence and greeting, providing relief and special comfort for those who are sick. Second, the impact of pastoral care services for patients is the fulfillment of patients' needs to be heard, supported, supported, guided. And third, helping patients to get out of problems or solve problems with the right attitude and decisions, good and right and can be accounted for. Patients are helped to overcome crises or problems that are happening in their lives. Thus, in general, pastoral care has an impact on services that complete human beings in all dimensions of their lives so that they can run well, normally and in balance. 
The influence of spiritual guidance based on research by Anisatun Nurfarida at RSUD Dr. Mowardi Surakarta, it can be concluded that there is an influence between the provision of spiritual guidance on patient anxiety as evidenced by the results of the following calculations: Spiritual guidance consisting of 30 questions for 80 patients are all valid, as well as the anxiety variable which consists of 30 items. All of the questions on 80 patients were also valid. So it can be concluded that the spiritual guidance variable from the 30 question items, each variable calculated using SPSS on 80 patients, none of them fell, and based on the results of the reliability test analysis, the Cronbach's alpha coefficient value for the spiritual guidance variable was 0.951 and the value of the Cronbach's alpha coefficient for the anxiety variable is 0.961 . From the two variables above that the coefficient value of Cronbach's alpha is more than 0.600 , it canconcluded from the two instruments that it can be to be said be 8 reliable and can be used as a real data collection tool the significance value of the spiritual guidance variable is 0.112 , this value is greater than the 0.05 significance level $(0.112>0.05)$ so it can be concluded that the spiritual guidance variable is normally distributed. Likewise with the anxiety variable from the table, it can be seen that the significance value of thevariable anxietyshows a significance of 0.146 , that the value also shows a significance greater than $0.05(0.146>0.05)$ so it can be concluded that the anxiety variable is normally distributed. The calculated $\mathrm{F}$ is 2.605 with a significance value of 0.001 . Therefore, the significance level of 0.001 is smaller than the significance level of $0.05(0.001>0.05)$, so it can be concluded that there is a linear relationship between spiritual guidance and patient anxiety $\mathrm{t}$ count of 11.518 and a significance of 0.000 is smaller than the coefficient level of 0.05 , so it can be said that there is a relationship between spiritual guidance and patient anxiety in Dr. Hospital Mowardi Surakarta. It can be seen that thevalue Standardized Coefficients shows -0.027 because thevalue Standardized Coefficients shows negative results, so it can be concluded that there is a negative influence, which means that the higher the spiritual guidance, the lower the patient's anxiety. Vice versa if the lower the spiritual guidance, the greater the anxiety of the patient. The contribution of the influence of spiritual guidance on the patient's anxiety is 0.027 or $2.7 \%$, with the meaning that the rest is influenced by other factors not examined by the researcher.

Research by Ilhamsyah who looked at the relationship between the implementation of spiritual nursing and the spiritual satisfaction of hospital patients showed a significant relationship between the implementation of spiritual nursing and the spiritual satisfaction of patients with a significance level of $P=0.033$. This is in line with what was conveyed by Suharmiati (2007), good service quality greatly affects patient satisfaction during treatment. This explains that the quality of service provided by the hospital will have a major influence on patient satisfaction, so to provide satisfaction for its patients, every hospital must provide satisfactory services. This study also shows that the implementation of spiritual nursing is not implemented but has spiritual satisfaction that is satisfied as many as 17 people and 28 people who say they are not satisfied. In other words, $37.8 \%$ of 
patients/respondents stated that the implementation of spiritual nursing was not implemented but still felt satisfied regarding the spiritual dimension. The frequency of respondents' characteristics that also affect aspects of spiritual satisfaction, for example, the majority of age are in middle adulthood, education, treatment experience and the patient's own psychological experience. In addition, the existence of policies and interventions from religious experts who make prayer visits to newly admitted patients is one part that plays a role in creating spiritual satisfaction for patients treated at Ibnu Sina Hospital Makassar. Respondents who were first treated at the Ibnu Sina Hospital Makassar and were satisfied as much as $44.2 \%$ and dissatisfied as much as $55.85 \%$ while respondents who had been treated in other hospitals felt satisfied as much as $26.7 \%$ and dissatisfied as much as $3 \%$. This is because respondents feel a significant comparison after being treated at another hospital. The existence of a different nursing service system raises expectations that are greater than what was experienced after being treated at the Ibnu Sina Hospital Makassar. While the respondents who were first treated felt dissatisfied as much as $55.8 \%$. according to the researcher's assumption, the respondent is also influenced by other characteristics of the respondent, such as the respondent's age and educational status at the time of treatment. This is in line with Nursalam (2012), which states that patient satisfaction is a subjective assessment of services. So that other factors experienced by respondents greatly affect the satisfaction. So in this study, different results were found, where the experience of being treated did not show a relationship between the experience of being cared for and spiritual satisfaction where $\mathrm{P}=0.085$.

This study also found that there was no relationship between patient education and patient spiritual satisfaction, where $\mathrm{P}=0.295$. Low education and high education have a relationship with the patient's spiritual satisfaction. This is slightly different from the research conducted by Syam (2010), that high intellectual experience can provide a broader view of spirituality so that it affects mental health. The other variables show that there is a relationship between the psychological situation experienced by the respondent and the patient's spiritual satisfaction. This is based on the value of $\mathrm{P}=0.162$. The psychological situation, both acceptance and rejection of the disease, does not provide significant meaning in the process of achieving spiritual satisfaction. The percentage in the elderly and unsatisfied age group is $66.7 \%$.

This is in accordance with research conducted by Syam (2010), that the higher a person's age, the higher the level of spiritual expectation. The higher the level of expectation, the higher the level of desire to be satisfied.From the results of this study, it can be concluded that there is a relationship between the implementation of spiritual nursing and the spiritual satisfaction of patients in the inpatient room of Ibnu Sina Hospital Makassar. So that the results of this study can be a reference for hospital management in an effort to increase patient spiritual satisfaction through the implementation of spiritual nursing. 


\section{CONCLUSION}

Healing or improving the condition of the patient does not only depend on the treatment and care provided by the health team, but also the spiritual experience of the patient, the assistance and spiritual services provided are very influential in increasing the motivation of the patient to recover from an illness. For further researchers who want to develop similar research on spiritual guidance and patient anxiety, it is expected to add more supporting methods of collecting and information such as interviews or observations and so on, conducting more in-depth and efficient research and is expected to include other variables that have not been studied in This research includes the level of religiosity, family support, environmental factors and so on.

\section{REFERENCES}

1. Aksoy, M., \& Coban, G. I. (2017). Nursing Student Perceptions of Spirituality and Spiritual Care. International Journal of Caring Sciences, 10(3), 1136-1147. doi: 10.1097/jnr.0b013e318263d956.

2. Alamsyah, D. (2015). The Great Pillars of Public Health Sciences. Yogyakarta: Nuha Medika.

3. Alligood, M. R., \& Tomey, A. N. (2006). Nursing Theorist and Their Work. ST. Louis: Mosby Elsevier, Inc.

4. Annafi, M. (2015). Optimism for Healing Drug Abusers (Descriptive Study at the Peace House Rehabilitation Center Semarang). University of Semarang.

5. Attard, J., \& Baldacchino, D. (2014). The Demand for Competencies in Spiritual Care in Nursing and Midwifery Education: A Literature Review. Care, 21(2), 214. doi: 10.4103/0973-1075.156506.

6. Azwar, S. (2018). Reliability and Validity. Yogyakarta: Dahlan Learning Library.

7. Black, J. M., \& Hawks, J. H. (2009). Medical Surgical Nursing; Clinical Management for Positive Outcomes. Philadelphia: WB Sounders Company.

8. Cartwright, K. B. (2001). Cognitive Developmental Theory and Spiritual Development. Journal of Adult Development, 8.

9. Clifford, G. (1973). Interpretation of Cultures. New York: Inc, Publishers.

10. Colaizzi, P. (1978). Psychological research as the phenomenologist's view it. In R. Vale \& M. King (Eds.), Existential-phenomenological alternatives for psychology (pp. 48-71). New York: Oxford University Press.

11. Donsu, T. (2017). Nursing Psychology. Yogyakarta: New Library Pres.

12. Faridah, V. N. (2016). Perubahan Persepsi Dan Domain Spiritual Terhadap Tekanan Darah Penderita Hipertensi Akibat Pemberian Spiritual Emotional Freedom Technique (SEFT) Virgianti Nur Faridah. Surya, 8(1), 60-71.

13. Farisa. (2017). The Effect of Islamic Spiritual Guidance on Patient Recovery Motivation at DR. Sardjito Hospital Yogyakarta. Sunan Kalijaga State Islamic University Yogyakarta.

14. Fika, D. (2015). Influence of Islamic Guidance toward Spiritual Meaning of Life (Research in Chronic Renal Failure Patients Undergoing Hemodialysis the Gunung Jati 
Hospital in Cirebon).

15. Hawari, D. (2016 a). Management of Stress, Anxiety and Depression. Jakarta: FKUI.

16. Hawari, D. (2016 b). Holistic Approach to Mental Disorders. Jakarta: FKUI.

17. Kalkim, A., Midilli, T., \& Baysal, E. (2016). An Investigation of the Perceptions and Practices of Nursing Students Regarding Spirituality and Spiritual Care. Religions, 7(8), 101. doi: 10.3390/rel7080101.

18. Khoirunnisa. (2017). The Role of Islamic Spiritual Guidance in Motivating the Healing of Inpatients at the Pringsewu Regional General Hospital (RSUD). UIN Raden Intan Lampung.

19. Mahmoodishan, G., Alhani, F., Ahmadi, F., \& Kazemnejd, A. (2010). Iranian Nurses' Perceptions of Spiritual and Spiritual Care: A Qualitative Content Analysis Study. Journal of Medical Ethics and History of Medicine, 3, 88-95.

20. Mashudi, F. (2012). Counseling Psychology - A Complete and Practical Guide to Applying Counseling Psychology. Yogyakarta: IRCiSoD.

21. Melhem, G. B. (2016). The Nurses \& amp; \#39; perceptions of spirituality and spiritual care giving: A comparison study among all health care sectors in Jordan. Indian Journal of Palliative Care, 22(1), 42. doi: 10.4103/0973-1075.173949.

22. Ministry of Health of the Republic of Indonesia. (2011). Hospital Accreditation Standards. Jakarta: Ministry of Health RI.

23. Nadhifah, J. (2008). The Relationship between Nurse-Client Therapeutic Communication with Motivation to Recover In Inpatients in Cempaka II Room RSD

24. Nanda. (2012). Nursing Diagnosis: Definitions \& Classification 2012-2014. In HT Herdman, Nursing Diagnosis: Definitions \& Classification (pp. 501-525). Jakarta: EGC.

25. Nurfariida. (2017). The Effect of Islamic Spiritual Guidance on Patient Healing Motivation at RSUP DR.Sarjitti Yogyakarta. Faculty of Da'wah and Communication, State Islamic University of Sunan Kalijaga Yogyakarta.

26. Nursalam. (2008). Concept and Learning of Nursing Research Methodology. Jakarta: Salemba Medika.

27. Raharjo. (2015). The Relationship Between The Level of Emotional Intelligence with the Communication Ability of the Piuted Nurse Students at Dr. Radjiman Wediodiningrat Lawang Mental Hospital. Brawijaya University Malang.

28. Rankin, E. A., \& Delashmutt, M. B. (2006). Finding Spirituality and Nursing Presence: The Student's Challenge. Journal of Holistic Nursing, 24(4), 282-288. doi: $10.1177 / 08981010106294423$.

29. Reed, P. G. (2008). Commentary on Spiritual Care Perspectives of Danish Registered Nurses. Journal of Holistic Nursing, 26(1), 15-16. doi: $10.1177 / 0898010108315189$.

30. Ross, L. (2014). Student Nurses Perceptions of Spirituality and Competence in Delivering Spiritual Care: A European Pilot Study. Nurse Education Today Elsevier Ltd, 34(5), 697-702. doi: 10.1016/j.nedt.2013.09.014.

31. Rostanti, R. (2016). Faculty of Usuludin and Islamic Thought, State University of Sunan Kali Jaga, Yogyakarta. Religion and its Implications for Patient Healing. 
32. Sari, M. P., \& Muin, M. (2009). Nurse's Perception of Spiritual Needs in the Technical Implementation Unit (UPTD) Surakarta Regional Hospital. Journal of Nursing, 3(1), 19-29.

33. Sianturi, N. (2016). Perceptions of Nurses and Nurse Managers about Spiritual Care in RSUD DR. Djoelham Binjai. Bukit Barisan Journal of Health, 1(1), 55-69.

34. Suharsimi, A. (2010). Research Procedure. Jakarta: Rineka Cipta.

35. Supriyanto. (2017). The Effect of Spiritual Guidance on Patients with Diabetes Mellitus at Sultan Agung Hospital Semarang. State University of Semarang.

36. Syafudin. (2016). Statistics of Medicine and Health: Jakarta: Epidemiology of Indonesia.

37. Tiew, L. H., \& Drury, V. (2012). Singapore Nursing Students' Perceptions and Attitudes about Spirituality and Spiritual Care in Practice: A Qualitative Study. Journal of Holistic Nursing, 30(3), 160-169. doi: 10.1177/0898010111435948.

38. Umar, F. (2016). The Effect of Spiritual Therapy on Healing Motivation in Inpatients in Internal Rooms and Surgery at Tani and Nelayang Hospitals, Bualemo Regency. State University of Gorontalo.

39. Wong, K. F., Lee, L. Y., \& Lee, J. K. (2008). Hongkong Enrolled Nurses Perceptions of Spirituality and Spiritual Care. International Nursing Review.

40. Yosep, I. (2016). Textbook of Mental Care. Bandung: Refika Aditama.

41. Yuwono, C. (2015). Overview of Nursing Students' Perceptions about Spiritual Care. Semarang: Diponegoro University. 